\title{
A REFLECTION AFTER 24 ,,TRAINING THE TRAINERS“ WORKSHOPS
}

\author{
IZKUŠNJE PO 24 DELAVNICAH UČENJE UČITELJEV \\ Zvonka Rener-Primec ${ }^{1}$, Vasilij Matko Cerar ${ }^{2}$, Vita Dolžan ${ }^{3}$, Lili Steblovnik², Miha Lučovnik², \\ Živa Novak Antolič
}

Prispelo: 24. 1. 2012 - Sprejeto: 18. 4. 2012

Original scientific article

UDC 61:374.7

\begin{abstract}
Introduction: With the rapid expansion of knowledge in medicine, there is a growing need for trainers who understand adult learning principles.

Methods: data from all the Training the Trainers (TTT) workshops, organized throughout a 4 year period, were retrospectively reviewed from questionnaires (which had been completed at the end of each TTT by all the participants).

Results: From March 2008 to the end of 2011, 24 TTT workshops have been organized: 19 basic, 3 advanced and 2 extra organized for specialists in cardiosurgery / anaesthesiologists and rehabilitation specialists. There were 160 participants, specialists from 28 various fields of medicine. Everyone completed a questionnaire and all but one gave positive feedback after the TTT as they effectively learned some new aspects of the adult teaching process. Discussion: Most participants during the TTT became aware that they lack an appropriate training background. The importance of assessment tools, feedback information and the evaluation of the learning process were considered very important by the majority of the participants. The connection between experience and the learning process requires motivation by the educator, who must be familiar with the use of appropriate learning theories and efficient teaching techniques. At the end of this process, a young specialist is expected to be competent in every field of daily practice as well as in unexpected emergency situations.
\end{abstract}

Conclusions: After 24 TTT workshops, the great majority of the participants had learned the essential elements of adult education methods and appreciated all the practical tasks in each TTT. Most of them would like to attend a TTT at least every second year.

Key words: training the trainers, medical education, feedback, learning, skills, attitude, adult, education

Izvirni znanstveni članek

UDK 61:374.7

\section{Izvleček}

Uvod: S hitrim razvojem novih znanj v medicini narašča tudi potreba po učiteljih, ki poznajo učinkovite principe učenja odraslih.

Metode: Retrospektivno so zbrani podatki vseh dosedanjih delavnic Učenje učiteljev, ki so potekale v zadnjih štirih letih, povzeti iz evalvacijskih vprašalnikov vseh udeležencev.

Rezultati: Od marca 2008 do konca leta 2011 je bilo organiziranih 24 delavnic Učenje učiteljev - 19 osnovnih, tri nadaljevalne in dodatno dve osnovni, organizirani za anesteziologe in specialiste rehabilitacije. Skupno je bilo 160 udeležencev, specialistov z 28 področij medicine. Vsi udeleženci , razen enega, so ob koncu delavnice podali pozitivno povratno informacijo, da so pridobili pomembna znanja s področja poučevanja in ocenjevanja odraslih.

Diskusija: Večina udeležencev na TTT je ozavestila, da ji primanjkuje ustreznega znanja, kako poučevati. Povezava med izkustvenim znanjem in procesom učenja specializanta zahteva motiviranega učitelja, ki pozna teoretične osnove in ustrezne tehnike poučevanja. Cilj poučevanja v poteku specializacije je, da bo mladi specialist ob koncu šolanja kompetenten na vseh področjih redne klinične prakse in tudi ob nepričakovanih urgentnih stanjih.

\footnotetext{
'University Medical Cetre Ljubljana, Division of Paediatrics - University Children's Hospital, University of Ljubljana, Faculty of Medicine, Chair of Paediatrics, Bohoričeva 20, 1000 Ljubljana, Slovenia

'University of Ljubljana, Medical Faculty, Department of Obstetrics and Gynaecology, Šlajmerjeva 4, 1000 Ljubljana, Slovenia

${ }^{3}$ University of Ljubljana, Faculty of Medicine , Institute of Biochemistry, Vrazov trg 2, 1000 Ljubljana, Slovenia

Correspondence to: e-mail: zvonka.rener@mf.uni-lj.si
} 


\section{Zaključki: Po 24 TTT-delavnicah je večina udeležencev je osvojila osnovne elemente edukacije odraslih in pohvalila} vse praktične vaje. Večina bi si želela sodelovati na TTT vsaj vsako drugo leto.

Ključne besede: učenje učiteljev, poučevanje v medicini, povratna informacija, učenje, veščine, odnos in obnašanje, odrasli, izobraževanje

\section{INTRODUCTION}

\subsection{Adult education}

As one of the most important human abilities, learning will always be necessary due to the expansion of knowledge, technologies, new skills and adaptation to new circumstances $(1,2)$. Adult education is a developing science like any other. In comparison to children, where education (for example in primary school) is obligatory and the teacher takes the initiative, motivation and evaluation, education in adulthood may go on for a person's whole life; it is based on personal decision, motivation and previous experiences, and it may change with the current situation (3-5). An adult student is motivated to learn to achieve a personal or professional career, too improve or change work or due to pure cognitive interest (6). In medicine, knowledge itself is never independent; namely, three aspects of learning and education in medicine have to be covered: knowledge, skills and attitude.

Knowledge has to be understood, transferred into a new situation, analysed and evaluated. The reinforcement of new knowledge should be theoretical and practical and a transfer to practice also needs to be based on the integration of the new with previous knowledge $(4,7,8)$. Learning skills evolves from watching and understanding all the necessary steps and procedures, followed by performing the skill under the trainer's guidance, and only then by the trainee alone. Reaching this stage, a trainee becomes competent in this skill and from here on can create a new or improved one $(4,5)$.

The third aspect of adult learning/education is attitude - the attitude towards yourself to become as good as possible in your knowledge and performance; the attitude towards colleagues and staff personnel (nurses and others); and attitude with regard to patients, which may all be reflected in daily behaviour and reactions in critical situations $(2,9)$. However, adult students may also have many obstacles that may interact with the learning process. They may be overloaded with too many obligations; they have families, they may have personality disorders, etc. (3).

Adult education principles are topics that have never been taught during the years of medical studies. We all learned about medicine, how to approach the patient, how to take history, how to decide on diagnostic procedures etc., but we have never been taught about the teaching techniques as trainers (1).

During specialisation, a young physician (trainee) works in various hospitals and clinics with trainers from many departments to learn specific skills and knowledge, getting experience as well as learning a professional attitude.

\subsection{The introduction of training the trainers (TTT) in the University Medical Centre, Ljubljana}

It all began with the initiative of the European Network of Trainees in Obstetrics and Gynaecology (ENTOG) with an argument that too much attention is given to the formal curriculum while there was no word at all about the minimal education for trainers (2).

The proposal for education for trainers was given to European Board and College of Obstetrics and Gynaecology (EBCOG). The president of the EBCOG Standing Committee for Training and Assessment was the last author. She succeeded with the initiative to organize the first »Training the Trainers" Workshop for EBCOG trainers by the Royal College of Obstetrics and Gynaecology, UK. At RCOG, these TTT courses have been in place already for 15 years (2). Slovenian doctors were among the first to join: the second author of this paper attended the first workshop and the second one, while the first advanced workshop was attended by the last author $(2,8)$.

In 2008, the initiative for "learning how to teach workshops « given by the last author, has been acknowledged by the Council for education of the University Medical Centre, Ljubljana. So the TTT workshops for medical education in Slovenia started. The main goal of the TTT is to improve the efficacy of the teaching process $(2,8)$.

The aim of the present study was to evaluate the results after 4 years of TTT workshops.

\section{METHODS}

\subsection{Study type}

We retrospectively reviewed the data collected from questionnaires completed by participants who attended the TTT workshops since 2008. We evaluated the 
number and specialisation of the participants, their preferences regarding the content of the TTT; their intention to motivate others to come to a TTT; and their opinion on how often they would attend such a TTT. There were 19 regular basic workshops, 2 additional ones due to special interest and 3 advanced TTTs (each workshop is a one day event).
We started with an evaluation of the questionnaires from the fourth TTT workshop and stopped with the 15th. After that, the Six Thinking Hats Method (De Bono E. Six Thinking Hats. Penguin Books 2000) was used, with the focus statement: how to improve the TTTs. The Six Thinking Hats or parallel thinking method gives the best results in a very short time as it allows lateral thinking.

Table 1. The programme of a basic TTT.

Tabela 1. Program osnovne TTT delavnice.

ORGANISED BY: UMCL Council for education

TRAINING THE TRAINERS (TTT)

Basic workshop

PROGRAMME

9.00: Greetings, the aims of the workshop, questionnaire

FEEDBACK INFORMATION

9.15: Short lecture on feedback information

9.30 - 10.20: EXERCISE 1: mini lecture

10.20 - 10.40: BREAK

TEACHING SKILLS

10.40 - 11.00: Short lecture on teaching skills in 4 steps; assessment

11.00 - 11.50: EXERCISE 2: teaching skills

11.50 - 12.30: BREAK

ASSESSMENT AND APPRAISAL

$12.30-12.45$ : Short lecture on assessment, MSF.

12.45 - 13.15: EXERCISE 3: assessment, role playing

13.15 - 13.30: Short lecture on appraisal.

13.30 - 14.00: EXERCISE 4. Introductory interview between trainer and trainee

14.00 - 14.15: BREAK

14.15 - 14.30: Short lecture on evaluation

14.30 - 15.45: EXERCISE 5: evaluation with Six Thinking Hats: how to improve the TTTs

15.45 - 16.00: TEST (questionnaire)

ORGANIZIRA: SVET ZA IZOBRAŽEVANJE UKCL

ZDRAVNIŠKA ZBORNICA PODELI sedem kreditnih točk

UČENJE UČITELJEV (TTT), osnovna delavnica

9.00: Pozdrav; cilji delavnice in preskus znanja

POVRATNA INFORMACIJA

9.15: Kratko predavanje o povratni informaciji

9.30-10.20: Vaja 1: Mini predavanje

10.20-10.40: Odmor

POUČEVANJE VEŠČINE

10.40-11.00: Kratko predavanje o poučevanju veščine - Strukturirano ocenjevanje veščin

11.00-11.50: Vaja 2: Poučevanje veščine

11.50-12.30: Odmor

OCENJEVANJE IN PRESOJA

12.30-12.55: Predavanje o ocenjevanju, presoji in o MSF

12.55-14.00: Vaja 3: Pogovor - presoja glavnega mentorja s specializantom. Igranje vlog.

14.00-14.15: Odmor

14.15-14.30: Kratko predavanje o paralelnem razmišljanju (6 klobukov)

14.30-15.45: Vaja 4: Vaja po metodi 6 klobukov

15.45-16.00: Preskus znanja 


\subsection{The structure of a TTT workshop}

A week before each workshop, all the participants receive presentations (in PowerPoint) via e-mail and instructions for homework tasks. Each workshop starts with a brief introduction of each participant and an overview of the programme. Participants also answer a questionnaire as an evaluation at the beginning of the workshop (the same questionnaire is then completed at the end of the workshop to assess the acquisition of new knowledge; the assessment rules are clearly stated on each questionnaire (Table 2.).

Table 2. Questionnaire.

Tabela 2: Vprašalnik.

Questionnaire

\section{EVALUATION OF THE TTT WORKSHOP AND FEEDBACK INFORMATION}

TTT no: UMCL date:

The aim of the workshop was to introduce and increase awareness about the basic elements of adult teaching principles. We would like to know your impression, opinion and suggestions for further improvement

\section{LECTURES AND EXERCISES}

1. Which lecture/exercise was the most important for you?

2. Why was it the most important?

3. Which lecture/exercise was the least important for you?

4. Why was it the least important?

5. Was the ratio between lectures and exercises: a) too many lectures b) too many exercises c) appropriate (mark one answer)

OVERALL ASSESSMENT

6. Please mark 3 words that describe your experience (feelings) at the TTT workshop

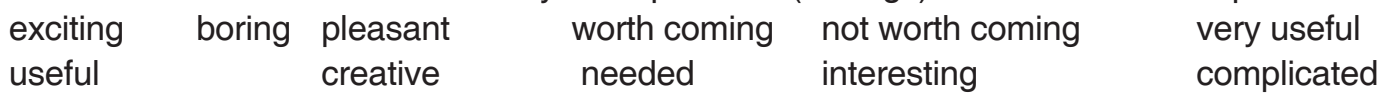

encouraging

7. Would you use any other word to describe the workshop?

8. What are you personally going to do that you were not able to do before the TTT?

9. Are you now going to change your work with students? yes, very a little not at all

10. Was the duration (length) of the workshop: appropriate too long too short

11. Was the group of participants: appropriate too small too large

12. Would you recommend a TTT to a colleague? Yes No

13. Should we continue with TTT workshops? Yes No

14. What would you change in the next TTT workshop?

15. What should definitely be kept in a TTT workshop?

16. Please finish this sentence:

As a trainer, I think that this workshop

THANK YOU VERY MUCH! IF YOU WOULD LIKE TO ADD A COMMENT, PLEASE USE THE SPACE BELOW. Prof dr Živa Novak Antolič, organiser, speaker, moderator

Doc dr Zvonka Rener Primec, speaker, moderator

Prof dr Marko Hawlina, president of Council for education UMCL

TTT številka:... UKCL datum:.......

OVREDNOTENJE DELAVNICE IN POVRATNA INFORMACIJA

Namen delavnice je bil seznanitev z osnovami poučevanja odraslih. Zelo nas zanima, kako uspešni smo bili pri tem.

Zato bomo zelo veseli, če boste ocenili delavnico in nam s povratno informacijo pomagali k še uspešnejšemu delu.

1. Kateri sklop (predavanje/vaja) je bil za vas najbolj potreben? - Obkrožite en sklop.
a) Povratna informacija
c) Ocenjevanje, presoja in MSF
b) Poučevanje veščine
d) Paralelno razmišljanje/6 klobukov 
2. Zakaj je bil ta sklop tako pomemben za vas?

3. Kateri sklop (predavanje/vaja) je bil za vas najmanj potreben? - Obkroži en sklop.
a) Povratna informacija
c) Ocenjevanje, presoja in MSF
b) Poučevanje veščine
d) Paralelno razmišljanje/6 klobukov

4. Zakaj je bil ta sklop najmanj pomemben za vas?

5. Ali naj v prihodnje: a) podaljšamo čas, namenjen vajam, in skrajšamo čas predavanj; b) skrajšamo čas vaj na račun predavanj; c) časovno razmerje naj ostane tako, kot je (obkrožite en odgovor)
SKUPNA OCENA:
1
2
34
56
$7 \quad 8$
89
10

6. Prosim, obkrožite tri besede, ki najbolje ponazarjajo vaša občutja o delavnici.

\begin{tabular}{|c|c|c|c|}
\hline zivajoče & Dolgočasno & Prijetno & Zoprno \\
\hline
\end{tabular}

7. Ali bi označili delavnico še s kakšno drugo besedo?

8. Kaj boste zdaj, ko ste opravili to delavnico, lahko delali, česar prej niste mogli?

9. Ali boste zdaj, ko ste opravili delavnico, spremenili svoje delovanje? (Obkrožite.)

$$
\text { Zelo Malo Sploh ne }
$$

10. Delavnica je bila:

11. Velikost skupine je bila:

$$
\text { ravno prav dolga predolga prekratka }
$$

$$
\text { primerna }
$$

12. Ali bi priporočili delavnico kolegu?

13. Ali naj nadaljujemo take delavnice?

prevelika

$\mathrm{Da}$

$\mathrm{Da}$

14. Kaj bi naredili drugače, če bi vi vodili naslednjo delavnico?

15. Kaj je nujno treba zadržati $v$ takih delavnicah $v$ prihodnje?

16. Prosim, končajte poved.

Kot mentor menim, da je ta delavnica ...

NAJLEPŠA HVALA.

ČE ŽELITE NAPISATI ŠE KAJ, PROSIM, UPORABITE TA PROSTOR.

The suggestions and proposals of participants from each workshop are taken into account in the next ones. All the workshops have a 15 minute theoretical introduction followed by practical exercise. Practical tasks practicing difficult situations between trainer and trainee would be presented as role play with two participants and then discussed in working groups. One of the practical tasks is also to teach a colleague a simple skill - step by step - and the evaluation of each demonstration is performed immediately. Pendleton's rules are used to guide the evaluation process (9).

The data analysis was mainly qualitative; each questionnaire was thoroughly read and the comments and conclusions were collated into groups. Descriptive text analysis was performed.

\section{RESULTS}

Since $13^{\text {th }}$ of March 2008, when the first TTT workshop started, 19 regular basic TTT workshops, 2 additional ones due to special interest and 3 advanced TTT2 have been organised. On average, there are four basic TTTs per year, organised on alternating days of the week (Tuesday, Wednesday or Thursday), except in 2009 when there were 5 workshops due to extra interest. There were from a minimum of two to a maximum of 10 participants per workshop, totalling 135 participants in 4 years attended basic the TTT workshops and an additional 25 participants in the advanced TTT2 workshops; the participants were specialists/trainers from 28 various fields of medicine. For details, see Table 3.

\subsection{Analysis of the questionnaires}

In the 12 TTT workshops evaluated using traditional questionnaires, there were 85 participants who responded. The answers to the question: what was the most important topic for you personally, were: for $28 \%$ of participants it was the lecture and exercise on giving proper feedback; for $25 \%$ of participants it was teaching a practical skill in four steps, for $19 \%$ it was appraisal; $14 \%$ thought all the lectures and exercises were equally important, $8 \%$ wrote that assessment was the most important, $4 \%$ thought the introduction interview with trainee role play was the most important and $2 \%$ thought multiple source feedback was the most important. 
Table 3. The participants in all TTT workshops (19 basic, 2 additional and 3 advanced).

Tabela 3. Udeleženci vseh TTT delavnic (19 osnovnih, dveh dodatnih in treh nadaljevalnih delavnic).

\begin{tabular}{|c|c|c|}
\hline & $\begin{array}{l}\text { Field of medicine (specialisation) / } \\
\text { Specializacija }\end{array}$ & $\begin{array}{l}\text { No } \\
\text { Št. }\end{array}$ \\
\hline 1 & Obstetrics and Gynaecology / Porodništvo in ginekologija & 34 \\
\hline 2 & Physiatry and Rehabilitation / Fizikalna medicina in rehabilitacija & 11 \\
\hline 3 & Internal medicine / Interna medicina & 10 \\
\hline 4 & Dermatovenerology / Dermatovenerologija & 11 \\
\hline 5 & Nevrology / Neurologija & 2 \\
\hline 6 & Nevrology, anaesthesiology / Neurologija, anesteziologija & 2 \\
\hline 7 & Paediatrics / Pediatrija & 10 \\
\hline 8 & Ophthalmology / Oftalmologija & 10 \\
\hline 9 & Otorhinolaryngology / Otorinolaringologija & 7 \\
\hline 10 & Cardio surgery, anaesthesiology / Kardiologija srca, anesteziologija & 4 \\
\hline 11 & Surgery / Kirurgija & 4 \\
\hline 12 & Infectious diseases / Nalezljive bolezni & 2 \\
\hline 13 & Psychiatry / Psihiatrija & 11 \\
\hline 14 & Surgery, travmatology Celje / Kirurgija, traumatologija Celje & 1 \\
\hline 15 & Surgery/maxillofacial and oral / Maksilofacialna in oralna kirurgija & 3 \\
\hline 16 & Dental medicine/children's health / Zobozdravstvo za otroke & 2 \\
\hline 17 & MWTS / Medicina dela, prometa in športa & 5 \\
\hline 18 & Medical Faculty (different institutes) / Medicinska fakulteta (inštituti) & 6 \\
\hline 19 & Clinical biochemistry inst. /UMCL / Klinična biokemija, UKC Ljubljana & 2 \\
\hline 20 & Anaesthesiology and reanimatology / Anesteziologija in reanimacija & 8 \\
\hline 21 & Pathology / Patologija & 2 \\
\hline 22 & Family medicine / Družinska medicina & 5 \\
\hline 23 & Radiology / Radiologija & 2 \\
\hline 24 & Clinical genetics / Klinična genetika & 1 \\
\hline 25 & Public health / Javno zdravje & 1 \\
\hline 26 & Occupational therapist / Medicina dela & 1 \\
\hline 27 & Paramedics/UMCL / Paramedicina & 1 \\
\hline \multirow[t]{2}{*}{28} & Pharmacology/UMCL / Farmakologija & 2 \\
\hline & ALL / vse & 160 \\
\hline
\end{tabular}

Legend: 2 additional TTT workshops were on organised Saturday for specialists from the Cardio surgery / anaesthesiology and the Physiatry and Rehabilitation departments.

Abr.: UMCL - University Medical Centre Ljubljana

MWTS - Medicine of work, traffic and sport

Legenda: dve dodatno organizirani TTT delavnici sta bili v soboto za specializante z oddelkov za kirurgijo srca, anesteziologijo ter fizikalno medicino in rehabilitacijo.

Kratice: UMCL - UKC Ljubljana

MWTS - Medicina dela, prometa in športa 
The answers to the question: what was the least important topic for you personally, were: $75 \%$ responded that all the topics were important. Among those who marked least important topics, $9 \%$ of all the participants thought that feedback exercise mini lecture was the least important.

The ratio between the lectures and exercises was appropriate for $88 \%, 1 \%$ suggested that there should be more lectures and less exercises and $11 \%$ would like more exercises and less lectures.

The answers to the question: what are you personally going to do that you were not able to do before this TTT workshop, were: $12 \%$ did not respond, $8 \%$ wrote that they would use proper feedback, $5 \%$ would use multiple source feedback, $4 \%$ of participants would teach practical skills differently; one would introduce a log-book for practical work, one would use role playing and one would perform introductory interviews. All the others, i.e. $68 \%$ responded that they would be able to do what already did in a better, more professional and more structured way, starting with the goals and communicating better with trainees and appraising them frequently. There were responses like: I now know clear requirements for me and the trainee; I will turn down demands that are not mine easier; I will self-reflect more; I will become a better role model.

Almost a quarter, i.e. $23 \%$ of the participants responded that they would change their work with trainees/students a lot; all the others responded that they would change it "a little".

Regarding the length of the TTT, it was appropriate for $85 \%, 8 \%$ of the participants thought the TTT was too long and $7 \%$ that it was too short. All the participants (100\%) responded with "yes" to recommending the TTT to a colleague and "yes" that you should go on organizing such workshops.

Regarding the question: What would you do differently if you organized such a workshop?, 67\% were satisfied with the TTT as it is and many interesting suggestions were written by the other $33 \%$ participants, ranging from more breaks with lunch to professional actors. $13 \%$ would have more real life scenarios with role play and facilitators to solutions.

What should definitely be kept in a TTT workshop? The participants were enchanted by the atmosphere of the workshop: $22 \%$ answered this question saying that they were most impressed by the humour, good will, relaxed attitude, inter-disciplinarily, playfulness and courage of the leaders. Smaller percentage answered this question regarding content and for $9 \%$, the role play of real life scenarios was what should remain by all means in future TTTs.
The TTT workshop was described as clearly useful by $51 \%$, (NB: everybody could use three of the adjectives given), as necessary and pleasant by $41 \%$ and $39 \%$ saw it as useful, interesting, exciting, worth of coming, encouraging and creative. When described in their own words, participants used adjectives as: not Slovenian (Slovenian people are supposed to be very introvert), surprising, relaxed, new, perfect, positive, creating better interpersonal communication, rich, extraordinary, fun and super fun, surprising and going forward. When asked what they think about the TTTs as tutors and trainers, $31 \%$ participants explicitly wrote that every tutor and trainer should attend; all the participants were convinced it is essential for everyone before they start teaching and training. Participants also wrote that it was one of the best educational moments they had; that it gave them material for personal growth; that trainees need the structure offered in the TTT; that they got new ideas on how to do their work better; that they would want such education every two years. They wrote that everything they were taught should be implemented in real life.

Because the programme of basic workshops always covered essential elements of adult education and learning principles, especially topics like motivation, feed-back information, reinforcement of knowledge, retention and transference of knowledge, skills and attitudes and also topics like responsibility, teamwork and communication, not one topic was considered redundant. The importance of good feedback information as one of the topics was also acknowledged by the majority of the participants as very important. Trainees will not be aware that their performance is not good if nobody tells them so. This feedback should improve the teaching process during training.

Each participant was asked to do home-work, so all participants were active. In this way, the great majority got also some personal experience. It was of interest how the atmosphere and content was more creative and active in the workshops with specialists from various fields, compared with the extra TTT workshops that were organised on Saturday for people with the same speciality (cardio surgery/anaesthesiology), who otherwise could not attend.

The assessment of surgical techniques is also briefly mentioned in the TTT and this topic is also well accepted by half of the participants. It is worth noting the comment of an expert that the real competence of a trainee in surgery would be performing an emergency operation at 2 o'clock in the morning, with a panicking relative hanging around a patient who is already in shock due to bleeding. 
As a part of the advanced TTTs - a test exercise to improve the skills for endoscopic procedures was available for each TTT participant: an excellent model (pelvic trainer) which has been introduced by doc. dr. M. Ribič Pucelj (Dept of Obstetrics and Gynaecology in Ljubljana) to improve the coordination of hand/ instrument movement in a three-dimensional way.

Seven invited lecturers from different fields of medicine (psychiatry and biochemistry) covered some aspects of learning techniques or coping with difficult trainees, which brought an additional creative atmosphere and inspired new solutions in the audience.

\section{DISCUSSION}

\subsection{The aim of the TTT workshops}

Although the results of this retrospective study are largely qualitative and descriptive, the most important result is that the TTT workshops period became well accepted during the 4 year. Twenty four workshops were attended by many different specialists, who became more active and got to know each other better thanks to the TTTs, which is also important in such a huge institution as the UKCL. This aspect is quite different compared to Europe, where TTT workshops are only organized by RCOG for gynaecologists and obstetricians (2). In addition, we realized that the atmosphere and content were more creative and active in workshops with specialists from various fields, so we conclude that this model of TTT, invented by the last author, can be regarded as an important added value.

\subsection{The main aspects of adult education covered by TTT}

At all our TTT workshops the essential elements of adult education - methods of learning, motivation, the reinforcement of knowledge, the retention and transference of knowledge, skills and attitude were largely discussed $(1,3,4,8)$.

The great majority $(75 \%)$ of participants responded that all the topics were important; $25 \%$ especially appreciated teaching a practical skill in four steps, and for $19 \%$ appraisal was the most important of all. Every participant got "homework" to do a week before the workshop - one of them, for example, was to prepare a task that another person has to learn (as a model of learning a new skill). It is very illustrative of how difficult can be to describe all the necessary steps of a new skill with words. In this way, the workshop becomes creative and relaxing at the same time $(2,5)$.

\subsection{The benefits of basic TTT}

The aim of TTT is to raise awareness about necessary knowledge and provide trainers with simple tools for dealing with the adult education process: how to teach special skills, how to influence the problematic behaviour of some trainees (11); how to motivate those who are too passive or how to guide others with not enough competence; and how to evaluate their progress $(2,10,11)$. These topics represent nearly half of the time in a basic TTT. In their responses about what they will be doing differently after a TTT, $8 \%$ will use proper feedback, $5 \%$ multisource feedback, $4 \%$ will teach skills differently etc. and $68 \%$ responded that they would improve what they do and do it in a better and more structured way. Almost a quarter $(23 \%)$ of the participants responded that they would change their work with students a lot. We should all be aware that at the end of specialisation, the supervisor must assess whether a trainee is competent to work independently and, if so, if he may proceed to the final exam. Namely, the most important mission of the supervisor is to lead the trainee to the point where he or she is truly competent.

The responsibility of good education rests on the supervisor and trainers, while the responsibility to learn on the trainee himself (7).

\subsection{The importance of good feedback information}

Assessment tools (and appraisal) are part of the basic TTT and this section was very much appreciated at each TTT workshop; it was considered the most important area by $19 \%$ of the participants. The first goal of a TTT was to discuss with trainers is the importance of the teaching process with regard to knowledge, skills and attitude $(3,6,7)$. And the evaluation of progress in each of these has to be programmed in advance and performed regularly in order to give trainees the best feedback information and so improve their learning and responsibility for both personal and professional development (7).

The importance of how feedback should be created in a positive atmosphere was always emphasized: how the trainer should praise, ask questions (and not simply criticize) and at the end of the day he/she should ask the trainees to each explain one thing that they have learned today $(4,12)$. Well formulated feedback information can increase the efficacy of learning and the self-competence of trainees, improving their skills and responsibilities. The positive aspect of feedback means avoiding destructive messages like: "You should never do it like that!" it is better to say: "let us try to do it this way"...) $(4,12)$. 
Trainers are often not aware that the timing of feedback is just as important as the content. Feedback should be given as soon as possible and in private, not in public, if something went wrong. A supervisor/trainer has to search for relevant information about the event and only listen to others afterwards. Avoid judgment; rather try to understand the reasons why something went wrong. Make notes, try to find a solution and encourage selfreflection by the trainee (4-6). Such topics were acted out as role playing, usually by 2 participants, followed by the vivid discussion of others.

\subsection{Some practical issues}

One of the topics in a TTT is how the teaching process is incorporated into daily clinical work. This has not changed much during the last few decades. Models of the learning/teaching process have been developed in order to speed up more efficient learning in clinical settings: for example a trainer and trainee work together in the same office, with the same selection of patients, with the purpose of explaining specific topics, discussing the role of important signs and symptoms, diagnostic procedures etc. In order to get best out of such teaching, enough time needs to be organized in advance so that there is time for questions and answers (12).

When a trainee becomes more skilled and knowledgeable, a parallel office is a good option, where each of them, trainer and trainee, may work independently but next-door, and where there is always the possibility to discuss diagnostic dilemmas or treatment etc. $(12,13)$. Discussion on this topic during each TTT was very active. A huge improvement has been accomplished with simulation centres, where students and trainees can learn with no risk to the patients $(14,15)$.

Training and testing on a model is now compulsory for trainees before an endoscopic procedure in a patient. A practical exercise on the trainer was also part of the advanced TTT workshop $(15,16)$.

\subsection{Communication and attitude}

The assessment of a trainee's attitude and behaviour is described in the article on multi-source feedback, a method that is included in the basic TTT (2). Trainees who are competent in communication with patients, colleagues and personnel usually also learn skills and acquire knowledge without major difficulties $(10,13)$. The communication skills were recognized as important by the majority of participants. Here, the role playing, where attendees play trainers or tutors and problematic trainees, nicely demonstrates the different aspects of poor communication or attitude. This topic directly resulted in the preparation of several Rules in UKCL; although not yet implemented, it is our obligation to bring them into practice.

Communication skills can be done with actors who act as patients (17). As mentioned above, role playing in our TTT helps recognize problematic behaviour. Close interaction with a real patient at the bedside, along with a trainer or teacher, is also needed $(2,13)$. In this aspect, a major advance has been taken with the introduction of professional tutors for students in the Ljubljana Medical School since 2009/10. The goal is that teachers/tutors should be responsible for the education and personal development of a young future physician $(2,18)$.

An excellent part of the advanced TTT was given by psychiatrists: it focused on empathy and self-reflection: how to recognise feelings such as anger and rage and how to react appropriately by talking about negative emotions but not reacting with them! It is very important to be alert and recognize what is going on in verbal and nonverbal communication $(19,20)$. Some time was also spent on communication axioms: different aspects of relations between members of the team, different perceptions, how a small change can create a different atmosphere while big changes might frighten some members of the team (19).

A good supervisor should be supportive, trustful and open to discussion and should pay attention to their mentoree (21). Empathy is important as a trustful attitude with a concordance in communication: the content of verbal information should never be different to that performed! (20).

\subsection{Who attended the TTTs?}

Attending such a workshop is on a voluntary basis and the choice arises in those trainers who already feel the need for more knowledge about teaching methods and techniques in adults and solving problems with problematic students. Medical professional knowledge and skills can be quite specialised and the consequences of the use of inappropriate techniques, timing or selection one might be devastating for the patient and, as a consequence, for the doctor, as well. Most participants responded that they would recommend TTTs to a colleague and the length was appropriate for $85 \%$ of them. Also the attributes of a TTT workshop: "useful, creative, needed, interesting and worth coming, excellent, etc. show that the assessment was overall very positive. This might be a bias as all the participants came of their own free will. 
All of us who participated in a TTT at first to learn and later also as contributors, very much appreciated sharing such rich experiences of learning how to teach in the nice atmosphere of the University Eye Hospital in Ljubljana, where the TTTs usually take place, and in the last year in the Medical Simulation Centre as well.

\section{CONCLUSION}

After 24 TTT workshops, the great majority of the participants learned the essential elements of adult education. Most of them would like to attend a TTT at least every second year.

Adult education is a continuously developing science offering more efficient and rewarding methods for medical training (specialisation).

\section{Acknowledgments}

We are much indebted to the following psychiatrists: doc.dr. Maja Rus Makovec, Vladka Stamos and Daša Troha, who are performing an excellent job in the TTTs regarding self-reflection, empathy and how to avoid burn-out. These issues are described in other articles. We are also very grateful to Ms. Klementa Habjan, Ms Meta Kovačič, Ms Martina Pečlin, dr Ivan Verdenik, Ms. Nuška Kotnik, Ms Marija Begelj for good will and organisational help.

\section{References}

1. Evans B, Armstrong D, Weinman J, Elliott L. Training trainers: a new approach for community medicine. Public 1990; 104: 3-8.

2. Novak Ž, Cerar VM, Rener-Primec Z, Dolžan V, Steblovnik L, Hawlina M. Why should one join a TTT program? Ask a colleague! - Or experience after a dozen of TTT workshops. Zdrav Vestn 2010; 79: 742-7.

3. Arogundade RA. Adult learning principles for effective teaching in radiology programmes: a review of the literature. West Afr $\mathrm{J}$ Med 2011; 30: 3-10.
4. Wood L, O‘Donnell E. Training the trainers: how to construct an educational half-day. Obstet Gynaecol 2001; 3: 213-7.

5. Blain J, McLure N. How we learn new skills: a beginner's guide. Obstet Gynaecol 2002; 4: 101-6.

6. Coomarasamy A, Khan K. What is the evidence that postgraduate teaching in evidence based medicine changes anything ?: a systematic review. BMJ 2004; 329: 1017.

7. Leung W. Competency based medical training: review. BMJ 2002; 325: 693-5.

8. Novak Ž. Učenje učiteljev ali zakaj bi se vendar mentorji učili kako učiti. Interno 2009: 14-5.

9. Pendelton D, Schofield T, Tate P, Havelock P. Pendelton $\square$ s rules: the new consultation. Oxford: Oxford University Press, 2004.

10. Maguie $P$, Pitceathly $C$. Key communication skills and how to acquire them. BMJ 2002; 325: 697-700.

11. Brafman $\mathrm{O}$, Brafman RS. The irresistible pull of irrational behaviour. 1st ed. New York: Doubleday Publishing Group, 2008.

12. Perdrix J, Gubser R, Gilgien W, Bischoff T. Added value of family practitioners' supervision of junior doctors in a walk-in clinic. Rev Med Suisse 2011; 18: 1095-1099.

13. O’Riordan M, Dahinden A, Aktürk Z, Ortiz JM, Dağdeviren N. Dealing with uncertainty in general practice: an essential skill for the general practitioner. Qual Prim Care 2011; 19: 175-81.

14. Molinas C, De Win G, Ritter O, Keckstein J, Miserez M, Campo R. Feasibility and construct validity of a novel laparoscopic skills testing and training model. Gyn Surg 2008. DOI 10.1007/ s10397-008-0391-0.

15. Thorson CM, Kelly JP, Forse RA, Turaga KK. Can we continue to ignore gender differences in performance on simulation trainers? J Laparoendosc Adv Surg Tech A 2011; 21: 329-33.

16. Molinas C, De Win G, Ritter O, Keckstein J, Miserez M, Campo R. Feasibility and construct validity of a novel laparoscopic skills testing and training model. Gyn Surg 2008. DOI 10.1007/ s10397-008-0391-0.

17. Scallan S, Ball K, Lyon-Maris J, Burrows P, Gorrod E. Using actors to simulate doctors in the continuing professional development of GP trainers and appraisers. Educ Prim Care 2011; 22: 171-7.

18. Medicinska fakulteta Univerze v Ljubljani. Accessed on: http:// www.mf.uni-lj.si/vsebina/menu1/1284.

19. Rus-Makovec M. Workshop on self-reflexion techniques - TTT. Ljubljana, 2010 (unpublished lectures).

20. Rogers R, Rayburn W. Teaching and evaluating surgical skills. Philadelphia: W.B. Saunders, 2006.

21. Boor K, Teunissen P, Scherpbier A, van der Vleuten C, van de Lande J, Scheele F. Residents' perceptions of the ideal clinical teacher - a qualitative study. Eur J Obstet Gynecol Reprod Biol 2008; 140: 152-7. 